\title{
Achieving Women Empowerment in Two Decades of Democracy in South Africa: A Wishful Dreamland?
}

\author{
M.A Mamabolo \\ M.P Sebola \\ Department of Public Administration,University of Limpopo, South Africa
}

Doi:10.5901/mjss.2014.v5n27p1079

\begin{abstract}
This paper is to evaluate the manifestation of democracy in South Africa as it reaches twenty years of existence. South Africa marks twenty years of democracy with the unanswered the extent at which women benefitted from democracy through authentic engagement in improving policies that directly address their needs and social protection. Policies on issues of gender and administration were passed since 1994 to benefit the women folk. But it has been argued that South Africa's democratic constitutional standing on implementation of policies passed since its inception has not been satisfactorily implemented. This paper will therefore argue for women empowerment at managerial positions and employment equity within the country, identify the missing gaps in showing that democracy as adopted per the constitutional founding is not authentic enough to take South Africa beyond its twenty years of democracy in achieving women empowerment. The paper conclude that South Africa need to review and upgrade policy implementation and look deeper into issues of women empowerment within the three spheres of government and generally improve the living conditions of its citizens.
\end{abstract}

Keywords: Democracy; Gender; Women Empowerment; Employment Equity

\section{Introduction}

South Africa's celebration of two decades of democracy has not answered a critical question of what has been achieved in the country about woman empowerment in the workplace. The Constitution of the Republic of South Africa which was firstly adopted in 1996, prescribed for security, fairness, equality and justice. All these issues were debated upon across the country and were to be implemented without hindrance and compromise. However the implementation and administration of issues such as fairness and equality remains a critical challenge in the country. In addition women empowerment is also among gender equality goal which the country aimed to achieve in all sectors though there are still some backlogs of women employment achievement which faces the society today. This is evidenced by minor change of gender equality at managerial or executive positions both in the public and private sector. This paper therefore will keep its relevance to the status of women in post 1994 democracy, the legislative framework governing woman empowerment, the feminism theory, and gender equity in South Africa.

\section{The Status of Women in Post 1994 Democracy}

Most women are employed in South Africa serve either as domestic workers or are running informal businesses of little benefit in financial terms. Chiloane-Tsoka (2011:299) argues that in South Africa despite the introduction of Broad Based Black Economic Empowerment policy contracts continued to be biased to big companies suffocating the potential of black South African women to benefit from economic policies. Such is what in essence keep the gender inequality in force in most developing countries. Aluko (2011:306) argues that gender disadvantage and poverty are two sides of the coin. In essence the Millennium Development Goals (MDG's) requires government to achieve 50/50 gender equivalence by 2015 (Vetten, Makhunga \& Leisegang, 2012: 1-15). This should include women in all different sectors of the country such as in politics and other forms of employment and economic sectors.

In South Africa the Business Women Association (BWA) reported a satisfactory increase in women assuming executive positions; however, $62 \%$ continues to be white women with only $25 \%$ being black women. Moeti \& Zondi (2010) have noted that in South Africa people are still not quite sure as to whether white women are indeed part of the designated group. The perception is that they might not have really suffered the injustices of the employment equity on equal basis with their black female counterparts. Sebola (2009), however argues that the concept women and disabled as 
used in the South African equality policies is not referring to a particular racial group in the South African society but applies to all South African women as beneficiaries. According to Ndhlovu (2011:316), the achievement by South Africa in this regard continues to be extremely lower compared to what Canada, Australia and the United States of America are achieving in terms of gender equality. Thus gender equality remains a problem area within the South African government which should be looked at and improved on.

The South African patriarchal societies stereotyped by culture also assume that women are of a weaker gender (Albertyn (2009:165-207; Sebola \& Khalo, 2010; Louw \& Kahn, 2011) and naturally incapable of making it in leadership and management positions. Consequently such promotes a continuous discrimination of women and gender inequality gaps. On the other hand there is a general perception that most women do not want to serve in senior positions of the public service and rather prefer to serve in the private sector or run their own businesses. Despite these assumptions emphasis on women empowerment, rights, protection and dignity remain significant. Cases of rape, sexual harassment and women abuse continues to be reported against women in the country on daily basis. In twenty years of democracy, gender equality in South Africa still seems unlikely to be achieved in absolute terms. Louw \& Kahn (2011) continues to emphasise that it would indeed take more than a century for gender equality in the South African working environment to be achieved. This is likely to be the case in the sense that often the figure of improvements in employment equity goes up and down as years passed by.

The South African government introduced policies and programmes which contribute to the development of women and empowerment so as to enable them to play a meaningful role in the society. Legislative frameworks such as the Constitution of the Republic of South Africa, 1996, Employment Equity Act, 1998, Affirmative Action, 1998 and Women Empowerment and Gender Equality Bill, 2013 govern women empowerment issues. These were passed to address the citizens' concern and give them access to economic and social benefits. They serve as a means of promoting women participation in politics of government and the society at large. However, the implementation thereof is still not achievable as envisaged.

\section{Legislative Framework Governing Gender in Post 1994}

The South African post-apartheid government introduced many policies which target gender equality in the country. Seidman (2001) however argued that the country took almost three years to come out with an enabling legislation and suitable budgets for addressing gender inequality. Gender issues and national institutions were however established in 1998 to mainstream gender activities. It is acknowledged that such policies have brought change to the country; however the implementation process of such policies is still questionable in evidence. The following legislative frameworks and policies were passed in post 1994 to improve the living conditions of women: the Constitution of the Republic of South Africa 1996, Employment Equity Act 1998, Affirmative Action, 1998 and Women Empowerment and Gender Equality Bill, 2013. The creation of these policies was indeed seen as a means to create a peaceful gender balance within the South African society.

\subsection{The Constitution of the Republic of South Africa, 1996}

It is stated in Chapter 2 of the Constitution, the Bill of Rights that all South African citizens have a right to be affirmed and enriched with democratic values of human dignity and equality. The Constitution of the Republic of South Africa, 1996 is the supreme law and is seen as a key instrument, because it sets out ground rules for the citizens and prohibits discrimination (Budlender 2002: 2). Given this human rights values, all citizens including the responsible government officials must therefore comply with such values and uplift the living conditions of its citizens. While human rights and equity issues are a major concern especially in the employment and the political activities of South Africa other authors cautioned political nepotism and token appointments in the public service (Gildenhuys, 1997:108; Sebola, 2009). This is what has been a major weakness of gender imbalances in developing countries.

\subsection{Employment Equity Act, Act 55 of 1998}

This act was established to promote equal opportunity and fair labour practice in the country (Sebola, 2009; Sebola \& Khalo, 2010). Its main purpose is to provide equality in the workplace with its preference on promoting equal opportunity and fair treatment in employment through the elimination of unfair discrimination; and implementing affirmative action measures to redress the disadvantages in employment experienced by designated groups, to ensure their equitable representation in all occupational categories and levels in the workforce. However arguments against the employment 
equity in the country are understood in different ways. Budlender (2002: 2) emphasise that the Constitution of the Republic of South Africa, 1996, pushes for the practical rather than formal equality which will push equality that will be grouped into different treatments. In the two decades of democracy in South Africa especially in the public sector there are still challenges in implementing these social issues. On other hand, it is true that the formal attention of the Act addresses equity of women who are working in the public sector because they are employed on basis of formal permanent contracts and neglects those who are employed on informal contracts. For example domestic workers, who are employed without any formal contracts are excluded in this regards. Women can therefore be protected only if they are employed on the basis of formal permanent contracts. This can only be practiced and implemented in the public sector, because it is the arm of government which employ people based on the existing policies of the country and applying Constitutional principles. Unlike in the private sector, women who are employed in this sector, permanent or on contract basis are likely to be protected than those in the private sectors who protect the investors' profit margins. This means that there is no equal practice by the public and private sector enterprises in the country. Hence Bornman, Budlener, Clarke, Manoek, van der Westhuizen and Waston (2013:21), adds that Employment Equity Act is still struggling to provide equality particularly for women in the workplace in South Africa.

\subsection{Affirmative Action Policy, 1998}

Affirmative Action (AA) was introduced in 1998 to counteract the effects of apartheid inheritance in the country. This legal framework aimed at eradicating economic disparity among people, for example achieving fair treatment in the public service, and in the private sector. The government enforces all employment sectors in the country to comply with the provisions of the Affirmative Action policy. The important question which remains difficult to answer is as to which extent does the government take action on companies or employers in the private sector that do not comply with the AA objectives? For example most Non-Governmental Organisations (NGOs) in South Africa are still dominated by the whites' male working class in senior positions. The argument for this is very clear that the private sectors still want to maximise profits for shareholders and cannot afford token appointments as the public sector does in the country. The argument around $\mathrm{AA}$ is that it can only promote and implement equal and fair treatment in public services. In the private sector most companies are family based and therefore the issue of fairness and equity is practiced with limited practical consideration. The issue of what works and what does not work drive the company's intends to satisfy the AA implementation objectives. Agenda (2012: 91-103) also noted that private companies in the country do not fully comply with the provisions of the employment equity policies to benefit women. Joubert and Calldo (2008) reported that the failures of the Affirmative Action policies are directly linked to its focus on racial numbers rather than the training and development of women in the country. That has indeed remained a problem of the AA policy which thus far makes it impossible for equity to be achieved in absolute terms in the employment sector of the country after two decades of democracy.

\subsection{Women Empowerment and Gender Equality Bill, 2013}

This Bill aimed at ensuring that all government departments and private companies fill a minimum of $50 \%$ of all senior and top management positions with women in the year 2015. However it is argued that in most private companies such requirement has not been sufficiently actioned. The Bill gives effect to Section 9 of the Constitution of the Republic of South Africa, 1996, which lays out the foundation of women empowerment and gender equality. It also establishes a legislative framework for the empowerment of women and enables them a representation of women in the decision making positions and structures. Chapter 2, Section 4 of this Act provides for issues of education and training for women. This emphasis on educational learning issues which are to be beneficial to women. If appropriately effected, the provisions of this Bill will give women access to opportunities, rights and services which they dreamt of in the last two decades. Despite the provisions of this Bill, South Africa continues to face the challenges of poverty, inequality and unemployment of women than before. The provision of this Bill expects all government departments and private companies to comply with gender transformation in the country.

\section{Towards Feminist Theory on Gender Equality and Women Empowerment}

Feminist Theory is an outgrowth of the general movement to empower women worldwide. The importance of this theory is to demonstrate the importance of women in the world and to bring out the issue of gender equality. This theory which is traceable to the work of Kate Millet in her book Sexual Politics argues that politics is a power structured relationship 
between the rulers and the ruled and therefore such relationships are revealing themselves in man and woman, child and adult, employer and employee and government and citizens' relationship (Heywood, 2007:12). The theory view the society as patriarchal and primary benefactors of the subordination of women in the society (Heinecken, 2002). Thus the notion of feminist is to fight for the equality of women and emphasise that women should have equal share of the socioeconomic benefits. Beall (2004:5) acknowledged that Feminist and gender activism in the country has always been most effective at the local level. However most proponents of the feminists' theory are of the view that there is a need for sexual revolution to overthrow men from his position, but moderate ones are of view that men should give them equal space of social benefits as themselves. This is in consideration that some women acknowledge the difference physical make up of man and women which differentiate the capabilities between the two human species. Heinecken (2002) argues that some radical feminists are propagating for a sexist position that women should be excluded from military ranks because their physical inferiority makes them unsuitable for combat activities. This will therefore as articulated by many scholars who conducted studies in the South African military find it difficult to confirm good gender numerical equity balance in the South African military services.

\section{Democracy, Changes of Gender Equity and Women Empowerment in South Africa}

In April, 27, 2014 South Africa celebrated twenty years of democracy and freedom. One of the most significant aspects of this democratic celebration is the issue of gender equality in the country. Gender equality implies a situation in which men and women enjoy same opportunities, rights, outcomes and obligations in all spheres of life (Wadesango, 2011). Bavinck (2013), however, contests that there is no a definite definition of gender equality or inequality and therefore subjecting the definition to contextual interpretations. Almost two decades after the end of apartheid in South Africa, the African National Congress (ANC) promised to undertake a broad action against gender inequality. However the pace of gender transformation changes in South Africa is still moving at a slow pace. Gender equality and women empowerment is a case that needs urgent and serious attention. Babugura(2010) emphasis that the issue of gender equality should not only be a women issues, but edged that men must make it their concern and work together with women to make this a reality in both principles and practice in the society. However on the other hand Khumalo (2013:1) argues that, gender equity has not only been rooted deeply in the workplace but rather at the society at large where it should start. Hence Dworkin, Colvin, Hatcher and Peacock (2012: 97) are of the belief that gender inequality contributes to violence and epidemics of HIVIAIDS in South Africa and around the globe. The country was supposed to have made a dramatic shift of equality since the dawn of its democracy; however, some writings have reported mild progress in achieving gender equality. The slowness of changes of equity in participating in the decision making process by women has been noted by many people in the country. It is notable that women empowerment in the country is insufficient with women participation characterised by under-representation at the executive level both in the public and private sector with little achievement in parliamentary seats.

Goko (2013:1) indicated that in the private sector women holds only $12 \%$ of senior and top management positions. This implies that even in the private sector South African women have not managed to close the gender equality gap. Thus women end up working in precarious forms of employment with low earnings and little financial security. Most women end up engaging themselves in livelihood activities in order to generate economic benefits and sustain themselves. This only explains why women earn less than what men are earning and the reason of their poverty and submissiveness in households. However this will differ with the type of work and job position women are holding. The World Economic Gender Gap Report (2013) revealed that in South Africa as compared to other countries, women earn less than men though they are doing the same job a practice which is believed to have been scrapped in the last two decades of democracy. This gives evidence that gender equality is far from being achieved in the workplace; however, there is existing government legislation which governs gender and employment equity in the workplace.

In South Africa women involvement in large infrastructure projects also remains a critical concern. Women are hardly employed in infrastructure projects such as roads construction in the country. According to the recent study conducted by Bornman et.al (2013:22), South Africa prioritise on large infrastructure projects such as road construction without gender consideration. The government allocate funds annually for the implementation and upgrading of roads and men are common beneficiaries in such projects than women. Hence that forces women to engage themselves in informal employment and run own small businesses. Government support to small businesses which are owned to participate in the country's economic growth is not satisfactorily. Chiloane-Tsoka (2011), however, argues that such perception differs regionally in South Africa. The effective government support will help in closing gender gaps particularly in formal employment. There has been a notable change of the level of men and women employment in formal employment. The engagement below excludes those engaged in informal employment. 
Gender changes at managerial positions from 2010 to 2013

Whilst a lot has been achieved in the country, much more needs to be done in achieving gender equity. Gender equality around the globe still has a long way to go, particularly in new democratic countries. Based on the vision of ensuring democratic issues, non-racism and non-sexism, the Commission for Gender Equality (CGE) was established as an independent statutory body in terms of Section 187, Chapter 9 of the Constitution of the Republic of South Africa, 1996. CGE is mandated to promote respect for gender equality and the protection, development and attainment of gender equality. However the positive achievement of gender equality remains a critical question that is not clearly answered. Rapoo \& Napo (2012:22) asserts that despite the existence of this various relevant laws to promote gender equity in the workplace, the progress of ensuring those rights is still unsatisfactory. The figure below seeks to highlights the changes of gender recognition in the country particularly those who are formally employed at top and senior management

Table 1: Gender changes for top management as of 2002-2012

\begin{tabular}{|c|c|c|c|c|c|c|}
\hline & $\mathbf{2 0 0 2}$ & $\mathbf{2 0 0 4}$ & $\mathbf{2 0 0 6}$ & $\mathbf{2 0 0 8}$ & $\mathbf{2 0 1 0}$ & $\mathbf{2 0 1 2}$ \\
\hline Male & $86.2 \%$ & $84.9 \%$ & $78.4 \%$ & $81.9 \%$ & $81.1 \%$ & $80.1 \%$ \\
\hline Female & $13.7 \%$ & $15.1 \%$ & $21.6 \%$ & $18.2 \%$ & $19.0 \%$ & $19.8 \%$ \\
\hline
\end{tabular}

Source: Solidarity Research Institution (2013), Commission on Employment Equity Annual Report (2013:9)

The above table illustrate a gender change of top management level with more male in 2002-2012. The table shows only a margin of a very slow progress in improving gender equality within the working environment. The reason for slow progress is not clearly known but readiness by South African women and lack of formal education and relevance to specific posts may limits opportunities for women in the workplace restricting them to accepting lower level paying jobs.

Table 2: Gender changes for senior management as of 2002-2012

\begin{tabular}{|c|c|c|c|c|c|c|}
\hline & $\mathbf{2 0 0 2}$ & $\mathbf{2 0 0 4}$ & $\mathbf{2 0 0 6}$ & $\mathbf{2 0 0 8}$ & $\mathbf{2 0 1 0}$ & $\mathbf{2 0 1 2}$ \\
\hline Male & $78.5 \%$ & $76.4 \%$ & $72.4 \%$ & $71.9 \%$ & $81.1 \%$ & $69.2 \%$ \\
\hline Female & $21.6 \%$ & $23.4 \%$ & $27.4 \%$ & $28.3 \%$ & $19.0 \%$ & $30.7 \%$ \\
\hline
\end{tabular}

Source: Solidarity Research Institution (2013), Commission on Employment Equity annual Report (2013:10)

The table above shows a significant progress by women occupying senior management level posts. The rate of progressing in equity is better but like in Table 1 the progress is not stable. While in Table 1 there has been a major decrease of males $(84,9 \%-78,4 \%)$ in top position in the year 2006 and a remarkable increase in top management position by women $(15,1 \%-21,6 \%)$. In Table 2 there was a significant continuous increase of women in senior management positions with the decrease in males from the years 2002-2008. Surprisingly there is significant increase of man in senior management positions and a terrible decrease of women in senior management positions. The reason for such inconsistency is not clear but it only tells us that gender inequality in the South African working environment continues as a problem that does not have an absolute solution.

\section{Gender and Employment Equity within the South African Political Level}

It is acknowledged globally that issues of Human rights are women's rights and women rights are human rights. As South Africa celebrates twenty years of democracy, human rights issues are at the forefront. Changes achieved in terms of gender equity are an important matter of address. Equality between women and men in South Africa in employment remains a pipe dream. Since the inception of democracy, the government and parliament undertook various measures to advance the position of women and to promote gender equality in all spheres of government. Vetten, Makunga \& Leisegang (2012:1) reported that women worldwide constitute only a small figure of $18 \%$ of parliamentarians worldwide. In the context of political empowerment for women, South Africa is not a worse case at all. Table 3, below show South Africa's level in terms of political empowerment and equality for women. 
Table 3: Global ranking and percentage of women parliamentarians in national parliaments

\begin{tabular}{|c|l|c|}
\hline Global Ranking & Country & Percentage \\
\hline 1 & Rwanda & $56.3 \%$ \\
\hline 2 & Andorra & $53.6 \%$ \\
\hline 3 & Sweden & $45.0 \%$ \\
\hline 4 & South Africa & $44.5 \%$ \\
\hline 5 & Cuba & $43.2 \%$ \\
\hline 48 & United Kingdom & $22.0 \%$ \\
\hline 60 & France & $18.9 \%$ \\
\hline 70 & United States & $16.7 \%$ \\
\hline 132 & Iran & $2.8 \%$ \\
\hline 133 & Bahrain & $2.5 \%$ \\
\hline 134 & Papa New Guinea & $0.9 \%$ \\
\hline 135 & Yemen & $0.3 \%$ \\
\hline 136 & Saudi Arabia & $0.0 \%$ \\
\hline
\end{tabular}

Source: Vetten et al. (2012)

South Africa is rated one of the best democracies when coming to political empowerment and equality for women. It is indeed rated number four in the global scale at women parliamentarians constituting $44,5 \%$ against male parliamentarians, however, it is rated lesser than Rwanda in which women constitute $56,3 \%$ of the parliamentary positions. Of significant in this argument is that gender equity consideration in South African parliament is considered to be higher than in The United Kingdom and the United States parliaments which regard themselves as champions of global democracy. South Africa's achievements in gender issues may be linked to its appointment of highly feminists' individuals as Commissioners (Seidman, 2001). Women empowerment and equity at political level in South Africa is not limited to the national parliament practice only, but also cascaded down to provincial politics. Mbadlanyana (2011:9) mentioned that women representation in local government is represented with $42 \%$ of women being councillors. However this representation decreased after the 2011 elections. It can be argued that gender equity in political environment of South Africa is easily achievable because there are no formal educational skills required other than mere populism in local communities. But gender equality issues remain a critical problem in formal employment of the public and the private sector as well as because of cultural stereotypes in the local communities.

\section{Conclusion}

This paper concludes that whilst a lot has been achieved, more needs to be done in achieving sufficient gender equity. There is still a great need for gender and employment equity in South African public and private sectors. While the country has made substantive gains in ensuring that women attain equal status to men through the existing pieces of laws issues concerning women equity to men are still critical. Women continue to suffer from poverty, unequal treatment and violence in the households.

\section{References}

Albertyn, C. 2009. 'The Stubborn Persistence of Patriarchy'? Gender Equality and Cultural Diversity in South Africa. Constitutional Court Review: 166-207. Pretoria: Government Printer.

Aluko, O.E. 2011. Gender, poverty and sustainable development in Nigeria. Proceedings of the $12^{\text {th }}$ Annual conference. International Academy of African Business and Development, May, 17-20, 2011, Edmonton, Canada.

Babugura, A., Mtshali, N., \& Mtshali, M., 2010. Gender and Climate Change: South Africa Case Study, Heinrich Bo"ll Foundation Southern Africa: Cape Town.

Bavinck, E.A. 2013. Conflicting Priorities? Issues of Gender Equality in South Africa's Customary Law. Amsterdam Law Forum, 5(2):2144.

Bornman, S., Budlener, D., Clarke, Y., Manoek, S.L., Van der Westhuizen, C., \& Waston, J., \& Antunes, S., and Igbal, N. 2013. The State of the Nation, Government Priorities and Women in South Africa. Cape Town: Women's Legal Centre.

Budlender, D. 2002. Gender Equality and Social Dialogue in South Africa: In cooperation with Industrial and Employment Relations Department. Switzerland: Bureau for Gender Equality.

Chiloane-Tsoka, G.E. 2011. The effect of tender document in empowering women entrepreneurs operating in small business in South 
Africa. Proceedings of the $12^{\text {th }}$ Annual conference. International Academy of African Business and Development, May, 17-20, 2011, Edmonton, Canada.

Goko, C. 2013. New Gender Equality Bill aims to 'change landscape' for South African women. Available online from: http://www.bdlive.co.za/business/new-gender-equality-bill-aims-to-change-landscape-for-SA.women. Accessed on 24 March 2014.

Heinecken, L. 2002. Affirming Gender equality: The Challenges Facing the South African Armed Forces. Current Sociology, 50(5):715728.

Joubert, P., \& Calldo, F. 2008. The Current Position of Affirmative Action. Pretoria: Solidarity Research Institution.

Kahn, S.B., \& Louw, V. 2011. Women 's Representativeness in the South African Public Service. Journal of Public Administration, 46(1): 669-682.

Khumalo, G. 2013. Celebrating 20 years of gender equality. South African Government News Agency. Pretoria: Government Printer. Available online from: http://www.sanews.gov.za/south-africa/celebrating-20-years-gender-equality. Accessed on 25 March 2014.

Moeti, K.B., \& Zondi, D. 2010. The State of Transformation in the South African Public Service: A case study of the national department of agriculture. Journal of Public Administration, 45 (1.1): 306-319

Ndhlovu, T.P. 2011. Is the glass ceiling cracking? Women and Economic empowerment in South Africa. Proceedings of the $12^{\text {th }}$ Annual conference. International Academy of African Business and Development, May, 17-20, 2011, Edmonton, Canada.

Rapoo, T., \& Napo, V. 2012. Gender Equality in the Workplace: Assessing Performance of Private and Public Sector Entities in South Africa. Johannesburg: South African Human Rights Commission Equality Report.

Republic of South Africa. 1996. The Constitution of the Republic of South Africa. Pretoria: Government Printer.

Republic of South Africa. 1998. Employment Equity Act. Pretoria: Government Printer.

Sebola, M. 2009. Affirmative action policy: the administrative efficient and socio-cultural impact on the South African society. Journal of Public Administration, 44(4):1102-1113.

Sebola, M., \& Khalo, T. 2010. Implementation of employment equity: a case of the University of Venda and of Pretoria. Journal of Public Administration, 45(1.1): 202-217.

Seidman, G.W. 2001. 'Strategic' Challenges to Gender inequality the South African Gender Commission. Ethnology, 2(2): $219-241$.

Solidarity Research Institution. 2013. A critical analysis of the $13^{\text {th }}$ Commission of Employment Equity report. Pretoria: Government Printer.

Vetten, L., Makhunga, L., \& Leisengang, A. 2012. Making Women's Representation in Parliament Count: The case of violence against women. South Africa: Womankind and the European Union.

Wadesango, N. 2011. Is gender Equity an Issue? Tensions and Contradictions Embeding the Work of Feminists Today. Journal of Social Science, 26(3):163-169. 